UDK: 336.71(4)

DOI: $10.2478 / j c b t p-2018-0017$

\section{An Analysis of the Determinants of Systemic Banking Crises in Southeast European Countries ${ }^{1}$}

\begin{abstract}
The purpose of this paper is to determine potential indicators of systemic banking crises in five Southeast European countries. Although signal horizon in the literature usually implies a period of 12 months before and 12 months after a crisis outbreak, models in this paper imply a 24-month pre-crisis period. Probability of a banking crisis occurrence is calculated using logit regression. Results have shown that banking system indicators have higher impact on probability of systemic banking crisis occurrence compared to macroeconomic indicators, and that the banking systems of these countries are significantly exposed to global trends.
\end{abstract}

Keywords: determinants of systemic banking crises, logit regression, Southeast European countries

JEL Classification: G01; C23; C25

\section{Introduction}

It has been proved throughout the history that banking crises usually have much more severe consequences on the

1 The most part of this research has been prepared during the author's two months stay at Vienna University of Economics and Business in 2015 with a scholarship awarded by the Scholarship Foundation of the Republic of Austria for post docs. The views expressed in this paper are those of the author and do not necessarily represent the position of the Central Bank of Montenegro.
${ }^{*}$ Central Bank of Montenegro, Podgorica, Montenegro

Email:

zeljka.asanovic@cbcg.me 
economy than crises emerging from other financial or non-financial institutions. This is due to a very specific role that the banking system has in an economy. While a liquidity crisis might be resolved within a few weeks, a systemic banking crisis might take years to be resolved. Taking into account very high costs of resolving systemic banking crises and their significant negative effects on the economy and, consequently, on the standard of living, a lot of attention ought to be dedicated to research on how and why crises happen in order to try to prevent their occurrence.

Stability of the banking sector is an issue to which economic policy holders devote a significant attention due to large expenses of resolving systemic banking crises and their frequent recurrence over the past three decades. Banking systems in developing economies have been under the influence of three important trends during previous few decades: privatization, consolidation and a growing entrance of foreign banks. Many developing countries have experienced systemic banking crises or have gone through severe problems within banking system during the transition process (for more details about banking crises in transition economies see: Tang, Zoli \& Klytchnikova, 2000). Key factors that contributed to crises occurrence in these countries were large amounts of inherited debts from previous socialistic regimes, as well as insufficient knowledge of enterprises and banks on market economy functioning (Tang, Zoli \& Klytchnikova, 2000). According to Cull \& Martinez Peria (2007), from the middle of 1990s, 77 systemic banking crises occurred. However, this number increased significantly afterwards due to the global economic crisis which showed that even the most developed countries are not spared from crises.

Given that the economic systems in developed countries are based on different institutional assumptions in comparison to developing countries, characteristics of the banking systems in developed countries differ from those in developing countries. Banks have a dominant role in the financial systems of developing countries; primarily in financing the private sector because the latter does not have enough accumulated own funds. Also, one of the main characteristics of their banking systems is a relatively simple structure compared to developed countries. Systemic banking crises result in cease of economic growth since financial intermediation is decreased which might lead to recession. In some cases, crisis of trust might have long-lasting consequences on the financial sector and, consequently, on the whole economy.

There is an extensive empirical literature on early warning systems for currency and banking crises. In general, there are two approaches for creating early warning systems that are most commonly used. The first one is a signal approach developed by Kaminsky \& Reinhart (1996), and Kaminsky, Lizondo \& Reinhart 
(1998), also known as KLR method. This approach compares behaviour of economic indicators for the period before and during the crisis. The second approach is based on the discrete dependent variable models, and it implies calculating the probability of banking crisis occurrence by estimating usually probit or logit model (Demirgüç-Kunt \& Detragiache, 1998; Eichengreen \& Rose, 1998). However, Davis \& Karim (2008) emphasize that the discrete dependent variable models (e.g. logit) are more adequate for creating early warning systems for group of countries while signal approach is more suitable for an individual country. The combination of these approaches is also possible, usually in a way that the first signal approach is applied and then the chosen indicators are estimated using logit or probit model ${ }^{2}$.The main idea of early warning models is that if factors triggering a crisis can be identified, then the occurrence of crises can be predicted. The aim of this paper is to analyse the determinants of banking crises in five Southeast European (SEE) countries. Namely, the selection of adequate indicators is the basis for creating early warning model for systemic banking crises. Therefore, this research represents an initial step in creating early warning model for systemic banking crises for these countries. This region is recognized as the least developed part of the Europe, and sound and stable banking system is one of the main prerequisites for economic growth and development.

The sample in this paper covers five countries: Montenegro, Serbia, FYR Macedonia, Bosnia and Herzegovina, and Croatia. Financial systems of these countries are mainly bank-dominated and largely foreign-owned by banks from the euro area. The paper focuses on identifying early warning indicators for systemic banking crises for these SEE countries since there is no similar research to the author's knowledge. However, it should be noted that there are papers on financial stability indicators and early warning systems for financial crises related to some of these countries individually (for Croatia see Dumičić, 2016; and Ahec Šonje, 1999 and 2002; and for Montenegro see Asanović, 2017) as well as the paper related to three countries (i.e. Macedonia, Croatia, and Turkey, see Bučevska, 2011).

The novelty of this study compared to some other works might be found primarily in some modifications with regard to the methodology compared to the approach usually used in literature. The main change relates to determination of the signal horizon which is usually set 12 months before and 12 months after the beginning of the crisis. However, since the objective of this paper is to deter-

2 However, there are other possibilities regarding combination of these two approaches. For example, signal approach might be used in order to create a composite index based on the indicators with the best performances, and afterwards logit regression where this index is the only independent variable is applied (See: Asanović, 2017). 
mine indicators that send signals among the first ones, the signal horizon is set 24 months prior to a systemic banking crisis. In addition, the beginning of the crisis is determined using different indicators in comparison with similar studies where NPL represents the indicator that is usually used. Due to changes in methodology, the results obtained in the paper are to some extent different in comparison to other similar studies.

The remainder of the paper is structured as follows. The second section presents stylized facts on the banking systems in these SEE countries, with the emphasis on credit expansion that happened prior to the crisis. The third section describes the methodology and availability of data, while logit regression as well as six simple logit regressions is estimated in the fourth section. The fifth section includes interpretation of results and discussion. Concluding remarks are presented in the seventh section.

\section{Stylized facts on the banking systems in SEE countries}

Western European banks for a short period experienced an expansion in the markets of Central and Southeast Europe. The largest number of banks in the countries of this part of Europe has a headquarters in Western Europe, reflecting the geographically close proximity, thus deepening economic integration, cultural closeness and existing or potential shared membership within EU (IMF, 2013, pp. 8). Western European banking groups have faced mainly saturated domestic markets, and also had access to increased liquidity at the global level. It seemed that the market in this part of Europe offers attractive conditions, including membership in the EU, institutions that are rapidly improving, income convergence, and initially a small banking sector. Therefore, rapid expansion was enabled within those countries.

Today, European banks have a significant presence in the banking systems of SEE countries. In addition, there is a high level of euroisation in these countries. The financial systems of SEE countries are significantly influenced by European banks, mainly from Austria, France, Italy, Greece and Slovenia. Increased financial globalization has helped in creating a more developed financial system and had other positive effects, such as reducing the cost of borrowing, higher quality financial services that have become widely available, risk diversification, technological and institutional spillover. But the region has thus become more vulnerable to external shocks. 
Although there are different views on the effects of the banking sector ownership structure on its stability, it is usually considered that the impact of foreign banks in developing countries reflects in: competition, efficiency, stability and increased access to credit for domestic borrowers. The presence of foreign banks suggests that host countries can become more exposed to external shocks, particularly those that affect the home countries of the foreign banks, which is evident in terms of the global economic crisis. Empirically, there is some evidence that the entry of foreign banks makes the banking system of the host country less vulnerable to domestic shocks, but also more vulnerable to external shocks. The study by Demirgüç-Kunt, Levine \& Min (1998) based on the paper Demirgüç-Kunt \& Detragiache (1998), shows that the presence of foreign banks reduces the likelihood of a banking crisis in a domestic country.

However, summarizing the results of the research Claessens \& Van Horen (2012) came to the conclusion that during the global economic crisis, foreign banks on average decreased lending activity more than domestic banks. In this way, foreign banks have likely contributed to financial instability although there are significant discrepancies documented by these authors. Still, when foreign banks are dominant in the banking system, it turns out that they are a more stable source of loans than domestic banks. Also, according to their findings, it is less likely that foreign banks will reduce lending since they have generated a significant portion of the funds from local deposits. Some foreign banks in late 2011 have begun to sell a number of their subsidiaries abroad due to lack of capital (Claessens \& Van Horen, 2012; p. 19). In general, efficiency was improved as foreign owned banks utilized risk management techniques. Accordingly, the compliance with international standards with regard to regulation and supervision of the banking industry has improved. One of the main developments in the banking sectors in SEE countries was relatively high credit growth during the pre-crisis period. As it might be seen in the next graph Montenegro had by far the highest credit growth of all countries in the region in the period before the crisis. Although enormous credit expansion in Montenegro seems to have significantly contributed to economic growth, it is evident that three-digit credit growth rates were based on unrealistic fundamentals.

\section{Graph 1: Credit growth y-o-y}

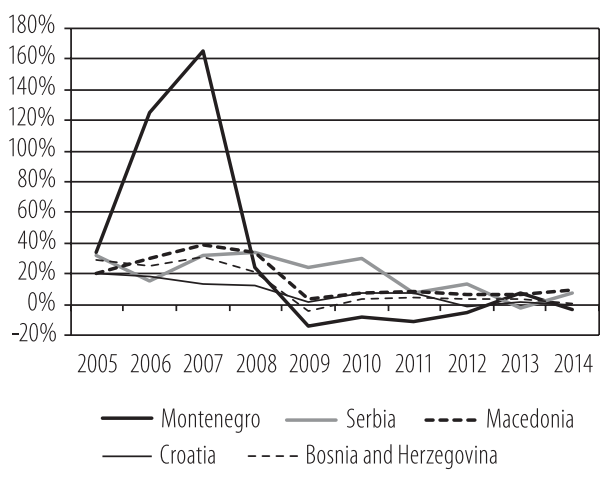

Source: Websites of reference central banks and financial institutions 
High level of non-performing loans (NPLs) is one of the key consequences of the crisis and represents one of the main challenges for monetary authorities in SEE countries in order to prevent stability and reliability of the banking system. Banks are mainly focused on managing NPLs and not on lending activity since they perceive credit risk as relatively high. The removal of NPLs to factoring companies has been helpful in reducing the NPL level within the banking sector,

Graph 2: Non-performing loans/total loans

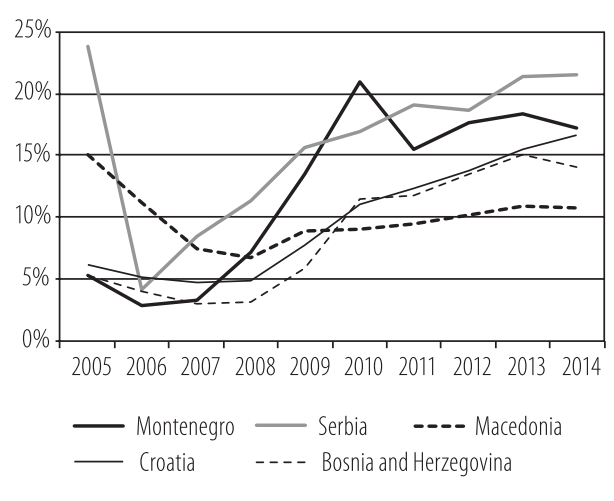

Source: Websites of reference central banks and financial institutions

\section{Graph 3: FDI (\% GDP)}

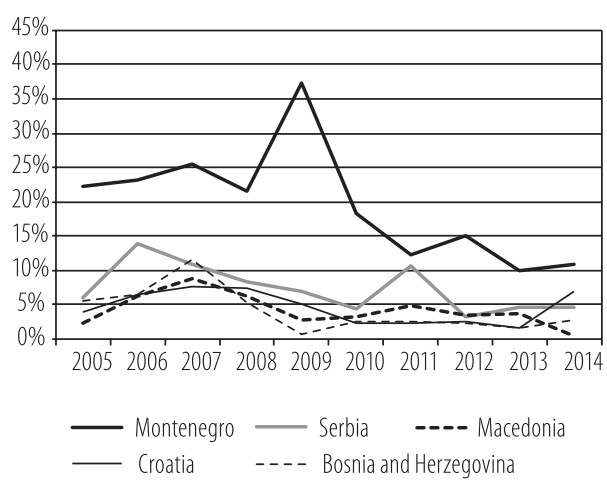

Source: UNCTAD but it does nothing to solve the underlying problem of borrowers' financial distress. The CESEE Bank Lending Survey prepared by the EIB finds that, while numerous factors affect credit growth, NPLs are the most important factor. ${ }^{3}$ Regulatory changes are also considered as an important constraint. If a bank has an adequate provisioning policy, it is possible to manage NPLs separately, leaving enough room for disbursing new loans. In general, too much emphasis is put on credit growth as a way of problem solving although there is no clear evidence that intensified credit activity will lead to stronger economic growth. It is important to find a long-term viable growth model based on improved allocation of capital and underlying corporate profitability which will simultaneously improve debt sustainability.

According to Estrin and Uvalić (2013), banking, telecommunications, real estate and retail trade have been among the most favoured sectors by foreign investors in the region. Estrin and Uvalić (2013) explore the determinants of foreign direct investment into eight transition economies in Southeast Europe:

3 The CESEE Bank Lending Survey is conducted twice a year, covering over 100 groups, both domestic and international. It includes a number of questions aimed at assessing demand and supply factors that may be driving credit growth. 
the six Western Balkan countries - Albania, Bosnia and Herzegovina, Croatia, Macedonia, Montenegro and Serbia, as well as Bulgaria and Romania, in comparison with the other transition economies. They emphasize that since the most SEE countries have attracted a large part of FDI primarily in non-tradable services, FDI have not contributed much to promoting exports or to industrial diversification and upgrading. Additionally, their empirical work indicates that political risk still seems to have a negative effect on FDI, but also that there is a positive correlation between the announcement of EU membership and FDI. The share of FDI in GDP was significantly higher in Montenegro compared to countries in the region, particularly in 2009. Namely, this ratio reached around 38\% in Montenegro during 2009, while it was much lower in the other sample countries, i.e. less than $7 \%$.

Graph 4 shows how real GDP growth varied throughout SEE countries in the pre-crisis and during the crisis period. There was a significant decline in GDP growth in mid-2009 when the observed countries recorded negative growth rates.

All countries from the sample, with the exception of Croatia, had very low values of the credit-to-GDP ratio in the period before the financial crisis. Although Montenegro had the lowest credit-to-GDP ratio of $17.5 \%$ in 2005 , it had the highest growth of this ratio in 2008 compared to other countries from the sample. This ratio reached $88 \%$ in Montenegro during 2008. However, after 2008 this ratio converged among these countries, with the exception of Croatia.

It should be emphasized that not every period when loans to private sector grow faster than nominal GDP is considered as lending boom (Ottens, Lambregts \& Poelhekke, 2005; pp. 1-3). Lending might temporarily grow faster compared to GDP due to companies' investments in working capi-

\section{Graph 4: Real GDP growth}

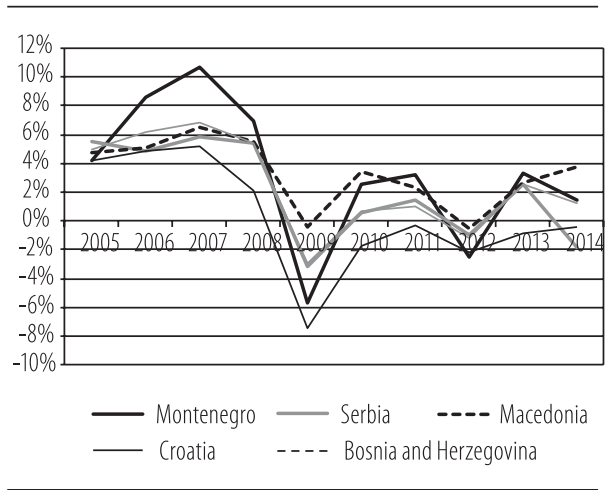

Source: Websites of reference central banks and financial institutions

\section{Graph 5: Credit-to-GDP ratio}

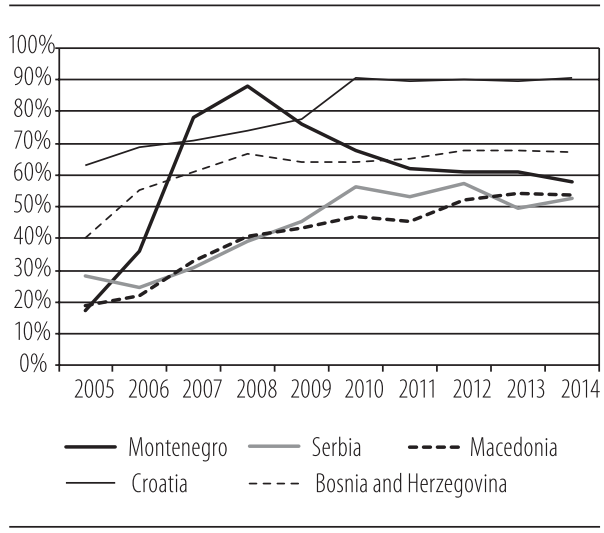

Source: World Bank 
tal when funds have to be paid in advance in order to maintain the production. Accordingly, often lending activity is fluctuating in front of the business cycles. Therefore, deviation that might exist between loans and GDP is not unusual. Also, credit growth may be above GDP growth during the longer period due to financial deepening which reflects increasing importance of the financial intermediation. A developed financial system might contribute to economic growth while lending boom represents the episode of exaggerated credit expansion that is unsustainable and which eventually leads to its own breakdown.

Sachs, Tornell \& Velasco (1996) are among the first ones that popularized the measure of credit growth to GDP during the previous 5 or 10 years (Frankel \& Saravelos, 2010; p. 14). They consider it a good indicator of increased vulnerability of the banking system since accelerated credit expansion probably happened due to a decrease in lending standards implemented by banks. Therefore, during the good times banks are lowering the criteria with regards to determining creditworthiness of borrowers in order to lend as much as possible and to increase market share. ${ }^{4}$ However, soon after the time of exaggerated liquidity passes, when the crisis occurs and economic activity slows down, all omissions made during the expansion surface primarily in the form of increased level of NPLs. When loans are growing faster than GDP, debt for the overall economy is increasing faster than funds for the repayment of the debt. This might be a sign that the banking sector is becoming more vulnerable. When volume of loans is increasing significantly faster than GDP, then the debt falls on the household and corporate sectors.

Schularick \& Taylor (2010) emphasize that at the beginning of 1980s there was an increase of authors who shared the opinion that mechanisms and the quantity of loans have higher impact compared to the level of money. ${ }^{5}$ Therefore, banks' balance sheet, assets and leverage may have macroeconomic implications. One of possible consequences is the reinforcement of the monetary transmission mechanism which represents the effect of financial accelerator. The other consequence might be financial sensitivity due to collateral limitations, when decreasing value of assets influences on lending activity, and decreasing productivity leads to further decrease of the assets value (Bernanke, Gertler \& Gilchrist, 1999). Schularick \& Taylor (2010) concluded that financial system is not only amplifier of the

\footnotetext{
4 The most alarming circumstance is when both borrowers and lenders are under the influence of excessive optimism, so neither of them do not make the selection of loan applications with due attention (Hardy and Tieman, 2008; pp. 5).

5 According to Schularick \& Taylor (2010), among the first ones are the papers of the following authors: Mishkin (1978), Bernanke (1983), Gertler (1988), Eckstein \& Sinai (1986), Kaufman (1986), relying on the ideas presented by Fisher (1933) and Gurley \& Shaw (1955).
} 
economic shocks in terms of financial accelerator, yet financial system is fully capable to create shocks itself $f^{6}$. They state that their conclusions confirm the ideas represented by Minsky (1977) and Kindleberger (1978) that financial system is prone to generating economic instability through endogenous credit booms.

Credit boom might happen due to different factors. Sometimes it may be caused by financial deregulation which increases banks' access to new credit markets. These reforms are usually followed by a decrease of provisioning in banks as well as by poorly regulated liberalization of capital account, which provides extensive liquidity that leads to credit boom (Cottarelli, Dell'Ariccia \& Vladkova-Hollar, $2003)^{7}$. Also, credit boom might happen due to large capital inflow caused by external factors (for example, low interest rates in developed economies) or during the periods of significant reduction of inflation (Gourinchas, Valdés \& Landerretche, 2001).

Kindleberger \& Aliber (2006) emphasize that the most of money expansions and loans do not lead to mania, and that there are much more economic expansions than manias, but that every mania is related to credit expansion. Laeven \& Valencia (2012) determined that within sample of 129 systemic banking crises that happened during the period from 1970 to 2011, and for which data on loans are known, credit boom preceded 45 crises $^{8}$.

A relatively simple structure of financial system is a common feature of the countries from the sample in this paper. Development of the banking sector in these countries during the pre-crisis period was characterized with relatively high credit growth rates. Economic slowdown and sudden stop of lending activity supported by the global economic crisis has led to much more deepening of the crisis in these countries at the time. During the expansion period, we should turn to saving to protect the economy from overheating and price bubble bursting, and that is exactly what was missing on the eve of the global financial crisis and what could have prevented or mitigated its impact (Fabris \& Galić, 2015).

6 However, some authors emphasize that high credit growth is not an independent source of shocks (Borio 2008, Hume \& Sentance 2009), i.e. that "credit chanel represents a mechanism of the increase i.e. that is not really independent or parallel chanel“ (Bernanke \& Gertler, 1995). See: Schularick \& Taylor (2010).

7 Ibidem.

8 Authors identified 147 banking crises in total, out of which 13 are "at the border", as well as 218 currency and 66 debt crises during the given period. For more details see: Laeven \& Valencia, 2012. 
Accordingly, it might be expected that the results of the research conducted in this paper will suggest that the credit boom and overheating of an economy play an important role as the indicators of systemic banking crises in SEE countries. Having in mind that countries from the sample are small and open economies with banking systems that are mainly foreign owned, it is expected that events on international markets have a significant impact on their banking systems, and therefore on the probability of the systemic banking crisis occurrence. This indicates that the global economic crisis has sharpened the imbalances in the domestic economies and consequently in the banking sectors of these countries.

\section{Methodology and availability of data}

Since systemic banking crises are harder to define than currency crisis, rules for determining date of the beginning of banking crisis are more varying comparing to currency crises (for more details see: Zhuang, 2005; p. 41-44). These rules might be classified into two categories:

1. indicators-based rules, and

2. event-based rules.

Indicators-based rules assume the use of numeric indicators like non-performing loans, costs of the banks bailout, losses of capital etc. However, there is no consensus in the literature about the critical values of those indicators in order to determine the start of the crisis. For example, Sheng (1996) uses 15\% of nonperforming loans as a threshold, while Demirgüç-Kunt \& Detragiache (1998) use $10 \%$ of nonperforming loans or cost of bailout at minimum of $2 \%$ BDP (Zhuang, 2005). The advantage of this method is that it enables monitoring and interpretation of trends in the banking system. Event-based rules include identification of the most important events related to individual banks or entire banking system, including bank runs, closures, mergers and acquisitions of the biggest financial institutions; or interventions of public sector in banking system.

According to Reinhart, Goldstein and Kaminsky (2000), most of the indicators which could be used in order to determine time when the crisis started are usually not available on monthly level but only on quarterly or even yearly level. Besides, some indicators (i.e. non-performing loans) often might be less reliable due to desire of banks to hide problems as longer as possible. Data relating to these indicators might be biased due to reporting problems or country specific regulations. Because of all these disadvantages the second method is more often used. The advantage of the second method is availability of the data i.e. information 
about relevant events, although it also has some shortages. Namely, if event-based rules are used, date of the beginning of crisis might be determined too late since financial problems usually start much earlier before e.g. a bank failed or before it is acquired. Also, date of the beginning of crisis might be determined too early because culmination of banking crisis comes much later (Reinhart, Goldstein \& Kaminsky, 2000).

Although there is no unique methodology towards determining the starting date of systemic banking crisis, the criterion commonly used is a share of non-performing loans in total loans at the level of a banking system. The threshold of $10 \%$ share of non-performing loans that is proposed by Demirgüç-Kunt \& Detragiache (1998) is usually used in literature.

However, the use of this ratio in the sample countries would lead to determining the crisis commencement much later than it actually was. Accordingly, that would affect the choice of an adequate signal horizon in this study. A share of nonperforming loans reaches $10 \%$ few quarters after the signs of crisis have already became obvious in all countries from the sample, except in Serbia where this ratio reached $10.18 \%$ in the third quarter of 2008. To wit, in Montenegro, the share of NPLs reached 10\% in 2009, while in Bosnia and Herzegovina and in Croatia this indicator reached $10 \%$ in 2010. Finally, in Macedonia this indicator reached $10 \%$ in 2012 . That is the reason why the author considered this criterion, although commonly used, as not being adequate for this research. Additionally, the definition of NPLs differs among these countries. Hence, although the author considered the use of indicators-based rules, the preference is given to event-based rules, i.e. not only numeric indicators but measures undertaken by monetary authorities are also taken into account. It might be concluded that the combination of these two approaches is implemented. Therefore, the beginning of the systemic banking crisis is the fourth quarter of 2008 for all countries except Croatia where the signs of crisis were obvious a quarter earlier. The rationale for determining the start of crisis in countries from the sample is briefly discussed below.

According to the threshold of a $10 \%$ share of nonperforming loans in total loans, the beginning of the systemic banking crisis in Montenegro should be the second quarter 2009 when this indicator reached $10.03 \%$. However, the author has determined the fourth quarter 2008 as the starting quarter of the crisis, when signs of the crisis had already been shown in the form of bank runs. Namely, in the fourth quarter 2008, deposits decreased by $-14.42 \%$ in comparison with the previous quarter. Further deposit withdrawal was prevented by measures undertaken by the Central Bank of Montenegro. 
The macroeconomic indicators in Serbia significantly deteriorated in the fourth quarter of 2008 due to the intensifying of the global crisis spillover to domestic economy. At the same time, the banking sector faced problems with liquidity and assets quality. A bank run in October 2008 was stopped at the end of 2008 owing to the set of measures undertaken by the National Bank of Serbia. Credit activity slowed down significantly in the fourth quarter of 2008 .

Lending activity in Macedonia started decreasing in mid-2008. The National Bank of Macedonia undertook several measures in order to maintain financial stability during 2008. Although Macedonian banks had enough liquid funds at their disposal during 2008, there was a pressure on banks' liquidity in the fourth quarter of 2008 due to heightened uncertainty among economic agents that came from global economic trends and more severe macroeconomic risks within the country. The increase in a share of foreign currency deposits imposed the necessity of maintaining stable exchange rate. Although the level of nonperforming loans became the main problem in the banking systems of these countries few quarters after the crisis emerged, that was not the case with Macedonia to such an extent. During the crisis period, a combination of standard and non-standard measures were undertaken by the monetary authorities in order to give additional support to credit activity improvement and, accordingly, to economic growth while preserving price and financial stability.

The Central Bank of Bosnia and Herzegovina (CBBH) undertook a series of measures during the fourth quarter of 2008 in order to maintain a stable and liquid banking system. These measures included a transfer of 200 million cash from abroad to domestic banks because there was higher demand for euros. Additionally, the $\mathrm{CBBH}$ reduced reserve requirements rate from $18 \%$ to $14 \%$ in October 2008 , and afterwards decided that all new credit lines which banks withdraw from abroad would not be subject to reserve requirement calculation from $1 \mathrm{No}$ vember 2008. Finally, the CBBH introduced differentiated reserve requirement rates in order to provide additional liquid funds for banks. Therefore, the author determined the fourth quarter of 2008 as the starting quarter of the crisis.

Real activity in Croatia started slowing down from mid-2008, and in the beginning of 2009 a significant recession took place (Bokan et al, 2009). Croatian exports started to decline in mid-2008 and imports also contracted. As Bokan et al (2009) emphasized, since mid-2008, credits to households virtually stopped while the lending to the private sector has slowed down further. Also, banks borrowed from their owners to obtain needed funds, especially during the deposit withdrawal in the last quarter of 2008. The Croatian National Bank abolished the 
marginal reserve requirements instrument in order to encourage foreign borrowing by banks as a way of providing necessary liquidity funds.

According to the literature signal horizon usually implies period of 12 months before and 12 months after the beginning of the crisis. Systemic banking crisis often reaches a peak few years after it starts since the duration of banking crisis most often is around 5 years (for more details see: Goldstein, 2005; p. 28, in: Asian Development Bank, 2005). Hence, there is a certain usefulness of getting the signal even after beginning of the crisis. The author has made some modifications related to determination of the signal horizon compared to the approach usually used in literature. Since the objective of this paper is to determine indicators that send signals among the first ones, the signal horizon is set 24 months prior to a systemic banking crisis. Although there is a certain benefit to get the signal 12 months after the beginning of the crisis, there is a significant advantage of determining the signal horizon only before the start of the crisis, not partially before and/or partially after the crisis outbreak. To wit, from the perspective of economic policyholders, it is desirable to get signals as earlier as possible in order to take timely corrective measures.

Potential indicators are selected mostly on the basis of the economic reasoning that takes into account theoretical assumptions and indicators already used in previous researches. Also, the choice of indicators depends largely on the availability of data. Besides the indicators related to countries from the sample, some additional indicators regarding the international environment are also taken into account.

As it is well known, a considerable number of variables regarding real economy and fiscal policy are available mostly on yearly basis. That is the reason why author decided not to take them into account, although some of them theoretically might be considered as early warning indicators for systemic banking crises. Similarly, data related to GDP and economic growth rate are not available on quarterly basis for long enough time period for some countries from the sample. Since these indicators are of great importance, the author obtained quarterly values using the method of linear interpolation. However, if there is an intention to use early warning models for systemic banking crises in practice, then these models should be adjusted to the essential nature of predicting. This means that the crisis signal should be received as earlier as possible and that certainly does not mean to have many variables in the model that are available on a yearly basis. Accordingly, GDP is not included in the final version of the model although it proved to be highly statistically significant in the preliminary estimated model. Index of industrial production is used as the adequate substitute, since this index 
is available on monthly or quarterly basis, which is much more in accordance with the essence of early warning models for systemic banking crises.

Variables in the paper are mostly expressed as natural logarithms, except indices, interest rates and exchange rates. The results of unit root tests showed that alltime series are non-stationary. Therefore, these time series are differentiated and by reapplying the tests after differentiating time series it is determined that they are stationary. A few time series have been differentiated two times in order to become stationary. Time series used in this paper range from q1 2005 to q4 2014 . It should be emphasized that the panel method is applied for this cross-country analysis, i.e. data are treated like a panel. Data are mostly taken from the referent websites of the international central banks. Definitions of variables used in the paper are given in the following table.

Table 1: Definitions of variables used in the paper

\begin{tabular}{ll}
\hline Variable & Definition \\
\hline LOANS & Total loans at the aggregate level of the banking system \\
\hline DEPOSITS & Total deposits at the aggregate level of the banking system \\
\hline CAPITAL & Total capital at the aggregate level of the banking system \\
\hline CAPITAL_ASSETS & Capital-to-assets coefficient at the aggregate level of the banking system \\
\hline LOAN_DEPOSIT & Loan-to-deposit ratio at the aggregate level of the banking system \\
\hline RESERVE_REQ & Total amount of reserve requirements at the aggregate level of the \\
\hdashline INFLATION & banking system \\
\hline IND_PRODUCTION & Annual growth rate of consumer prices \\
\hdashline UNEMPLOYED & Number of unemployed persons \\
\hline WHEAT_PR & Price of wheat at the global level, in Euro per metric ton \\
\hdashline OIL_PR & Price of crude oil at the global level, in Euro per barrel \\
\hline EXCHANGE_R & Exchange rate \\
\hline EURIBOR_1M & 1-month EURIBOR \\
\hline EURIBOR_3M & 3-month EURIBOR \\
\hline
\end{tabular}

\section{Estimation of logit regression models}

Discrete dependent variable models are commonly used in order to create early warning models for banking crises. These models establish a link between a dependent variable that represents the banking crisis and the indicators of crisis that are represented by independent variables. Generally, these models have been used in order to predict mainly currency crisis, while their application for early 
warning systems for systemic banking crises is growing in recent years. This can be attributed to the fact that throughout the history currency crises occurred more often compared to banking crises. However, there is a noticeable increase in frequency of recent banking crises.

The possibility of choice between two options is represented by a model in which the dependent variable $y$ is binary and takes value 1 when one choice is made and 0 when another choice is made (for the detailed explanation see: Gujarati, 2004). If the likelihood of the first choice is denoted by $\mathrm{P}$ (and the probability of the second choice is 1-P), it is important to determine this probability and to describe the impact of various factors on it. In most of the existing literature on crises, crisis probability is calculated by estimating the logit regression model where the dependent variable (for each month, quarter or year) takes value 1 if that period is classified as a crisis and the value 0 if there is no crisis. The results of the estimated logit model are presented in the following table.

Table 2: Estimation results of logit model

\begin{tabular}{|c|c|c|}
\hline Variable & Coefficient & Statistical significance \\
\hline LOANS & -48.73 & 0.001 \\
\hline DEPOSITS_1 & 51.96 & 0.001 \\
\hline CAPITAL & 57.88 & 0.001 \\
\hline RESERVE_REQ_1 & 9.22 & 0.044 \\
\hline INFLATION_2 & 0.52 & 0.043 \\
\hline IND_PRODUCTION_1 & 0.07 & 0.069 \\
\hline EURIBOR_1M_1 & -2.31 & 0.056 \\
\hline EXCHANGE_R_1 & -1.23 & 0.004 \\
\hline CAPITAL_ASSETS & -36.40 & 0.006 \\
\hline UNEMPLOYED_1 & -14.68 & 0.050 \\
\hline Const & -5.23 & 0.000 \\
\hline
\end{tabular}

Source: Author's calculations in Stata

Coefficients in the logit model show only the direction of change in probability, thus it shall be necessary to calculate marginal effects in order to determine the size of change in probability of systemic banking crisis occurrence. Since logit is a non-linear model, there is no single marginal effect of a variable but an average marginal effect, which means that marginal effect changes with the value of a variable itself. Accordingly, although intuitively marginal effect should be lower than 1 (or equal to 1 ) since probability ranges between 0 and 1 , it can happen that it is greater than 1 . Therefore, in the logit model, marginal effect represents an ap- 
proximate change in the dependent variable y for a one-unit change in explanatory variable $x$. Marginal effects of explanatory variables on dependent variable are presented in the following table.

Table 3: Marginal effects

\begin{tabular}{|c|c|c|}
\hline Variable & Marginal effects & Statistical significance \\
\hline LOANS & -1.54 & 0.049 \\
\hline DEPOSITS_1 & 1.64 & 0.029 \\
\hline CAPITAL & 1.83 & 0.058 \\
\hline RESERVE_REQ_1 & 0.29 & 0.128 \\
\hline INFLATION_2 & 0.02 & 0.077 \\
\hline IND_PRODUCTION_1 & 0.01 & 0.142 \\
\hline EURIBOR_1M_1 & -0.07 & 0.097 \\
\hline EXCHANGE_R_1 & -0.04 & 0.031 \\
\hline CAPITAL_ASSETS & -1.15 & 0.073 \\
\hline UNEMPLOYED_1 & -0.46 & 0.112 \\
\hline
\end{tabular}

Source: Author's calculations in Stata

It should be emphasized that marginal effects for three out of ten variables in the model are not statistically significant. This might be because of weak performance of these indicators or due to the correlation between explanatory variables so the author checked the values of correlation coefficients between the variables. The correlation coefficient between capital and capital-to-assets ratio is 0.81 which certainly causes a concern. In order to be completely sure about the existence of correlation between explanatory variables, the Variance Inflation Factor has also been calculated. Since the value of VIF for any of these variables does not exceed 4 , the correlation between them might not be an issue. Additionally, because the emphasis is on the predictive power of the model, many authors suggest that multicollinearity is not an important issue that should be particularly addressed.

In economic literature dedicated to early warning models for banking crises, some authors (Jagtiani et al., 2003, and Davis \& Karim, 2008) came to a conclusion that the predictive accuracy of simple logit model, which has only two explanatory variables, exceeds the performances of one complex multivariate model (Dardac \& Boitan, 2009; p. 77). Dardac \& Boitan (2009) came to the same conclusion in their research. They had a small sample (38 observations for the period from the third quarter of 1997 to the fourth quarter of 2006) at their disposal and they tested a series of simple logistic regressions which are comprised of the dependent variable and a maximum of two independent variables. Namely, 
the best predictive performance was achieved in models with a maximum of two independent variables.

Six simple logit models with at most two explanatory variables are estimated. The results of the estimated models as well as marginal effects of explanatory variables are presented in the following table.

Table 4. Estimation results of simple logit models

\begin{tabular}{|c|c|c|c|c|c|}
\hline Model & Variable & Coefficient & $\begin{array}{c}\text { Statistical } \\
\text { significance }\end{array}$ & $\begin{array}{l}\text { Marginal } \\
\text { effects }\end{array}$ & $\begin{array}{c}\text { Statistical } \\
\text { significance }\end{array}$ \\
\hline \multirow{2}{*}{ Model 1} & DEPOSITS_2 & 21.48 & 0.000 & 3.11 & 0.000 \\
\hline & CAPITAL_ASSETS_1 & 6.34 & 0.090 & 0.92 & 0.083 \\
\hline \multirow{2}{*}{ Model 2} & LOANS & -12.82 & 0.032 & -1.95 & 0.030 \\
\hline & CAPITAL & 15.77 & 0.000 & 2.39 & 0.000 \\
\hline \multirow{2}{*}{ Model 3} & RESERVE_REQ_1 & 4.43 & 0.006 & 0.72 & 0.005 \\
\hline & EXCHANGE_R_1 & -0.35 & 0.015 & -0.06 & 0.012 \\
\hline \multirow{2}{*}{ Model 4} & WHEAT_PR_1 & 2.28 & 0.067 & 0.36 & 0.063 \\
\hline & EURIBOR_3M & -1.09 & 0.021 & -0.17 & 0.017 \\
\hline \multirow{2}{*}{ Model 5} & OIL_PR_1 & 5.34 & 0.001 & 0.79 & 0.000 \\
\hline & EURIBOR_1M & -2.76 & 0.001 & -0.41 & 0.000 \\
\hline \multirow{2}{*}{ Model 6} & LOAN_DEPOSIT & 23.08 & 0.000 & 3.27 & 0.000 \\
\hline & UNEMPLOYED_1 & -13.51 & 0.001 & -1.91 & 0.001 \\
\hline
\end{tabular}

Source: Author's calculations in Stata

\section{Interpretation and discussion}

The results of the estimated logit model suggest that the level of capital has the highest marginal effect on the dependent variable. If capital, deposits, reserve requirements, inflation, and industrial production increase, the probability of crisis tends to increase. On the other hand, if loans, Euribor, exchange rate, capital-toassets ratio, and unemployment increase the estimated probability of systemic banking crisis occurrence tends to decrease. However, the marginal effects for reserve requirements, industrial production and the number of unemployed persons are not statistically significant although these variables are statistically significant within the estimated model.

After the onset of the global economic crisis, the key central banks (i.e. FED, Bank of England, and ECB) have drastically reduced their reference interest rates. The main reason why the benchmark interest rates are at the historically low level 
is the debt crisis that has taken hold, particularly in some EU countries. Since there is a slowdown in economic activity, reducing the benchmark interest rates represents an attempt to prevent the occurrence of recession and to stimulate economic growth.

It should be emphasized that Montenegro and Bosnia and Herzegovina have fixed exchange rate regimes. In general, one of the main advantages of fixed exchange rate regimes is that they enable achieving macroeconomic stability owing to a solid nominal anchor. However, fixed exchange rates do not a priori provide macroeconomic stability. The main deficiency of fixed exchange rates is that they reduce flexibility of monetary policy. Yet, it should be emphasized that foreign currency lending might pose significant credit risk in countries with no currency anchor.

Six simple logit regressions that individually have two explanatory variables are estimated. The results suggest that the loan-to-deposit ratio has the highest marginal effect on the dependent variable. This ratio is commonly used for assessing liquidity of a bank. A very high ratio might indicate that a bank does not have enough liquidity to cover any unforeseen emergencies. However, a very low ratio might suggest that a bank is not earning as much as it can on deposits.

Additionally, if the number of unemployed persons, deposits, capital-to-assets ratio, capital and reserve requirements, and the price of the wheat and oil prices increase, the probability of systemic banking crisis occurrence tends to increase. On the other hand, if loans, 1-month Euribor, 3-month Euribor, exchange rate increase, the probability of systemic banking crisis tends to decrease.

Although the reserve requirements instrument is used in developed market economies only to a small extent, it is much more important for developing countries. All countries in the region have relaxed their reserve requirement policies in order to improve liquidity and lending activity as of the global financial crisis outbreak.

It might be noted that three variables that have the highest marginal effects within the previously estimated logit regression are also among the ones that have the highest marginal effects within the six simple logit regressions. These variables are: capital, deposits and loans.

Although the results of the six simple logit regressions largely coincide with results of the previously estimated logit model there are some issues that need to be addressed. Two variables that were statistically significant in the previously estimated logit model, i.e. inflation and industrial production, did not prove to 
be statistically significant in any of the simple logit regressions. Therefore, these variables are excluded from the final specifications.

However, few additional variables prove to be statistically significant, among which the most important are the global prices of wheat and oil. This might suggest that these economies are significantly exposed to trends on the global level. Accordingly, developments on international markets have a significant impact on the banking systems of these countries and, therefore, on the probability of systemic banking crisis occurrence.

At first glance, some of the outcomes from the estimated models might be considered as counterintuitive. However, economic interpretation of the results is largely dependent upon the modification related to determination of the signal horizon. Namely, as it is previously stated, the author has made a modification of the approach usually used in literature. Since the objective of this paper is to determine the indicators that send signals among the first ones, the signal horizon is set at 24 months preceding a systemic banking crisis, as opposed to the usual signal horizon of 12 months before and 12 months after the beginning of the crisis. Taking this into consideration, it is expected that results may differ when using a different signal horizon.

For example, in many similar studies, deposit outflow is related to a greater crisis probability, which is certainly true. However, when deposit outflow happens that means that the crisis has already started, so one actually does not need an early warning model for banking crisis. The more important thing is to analyse what happens with the banking system and the overall economy during two or three years before the crisis. That is why a significant growth in deposits might suggest that there is excess liquidity in the given banking system, which could have some negative implications and lead to additional problems. Similarly, a decrease in unemployment may be related to the expansion cycle which indicates that the overheating of an economy may be related to the systemic banking crisis occurrence.

Interestingly, the indicator that represents loans has a negative sign which indicates that if loans increase, the estimated probability of systemic banking crisis occurrence tends to decrease. Hence, this might suggest that credit growths in SEE countries actually had not been exaggerated, with the exception of Montenegro. In accordance with this assumption, the credit boom indicator plays a dominant role owing to very good performances in early warning models for systemic banking crises in Montenegro (Asanović, 2017). 


\section{Concluding remarks}

Although the countries from the sample have similar economies, they differ from each other. The differences might come due to various foreign exchange regimes in these countries. Accordingly, Montenegro is a euroised economy while Bosnia and Herzegovina has the currency board; therefore, both of these countries have very limited monetary policy instruments at their disposal, which is not the case with Serbia, Macedonia and Croatia. Taking into account results of logit regression as well as results of simple logit regressions it may be concluded that indicators related to banking system have higher impact on probability of systemic banking occurrence compared to macroeconomic indicators. The results also have shown that banking systems of these countries are significantly exposed to trends on the global level.

The main conclusion that might be drawn is that there are usually indicators that point to weaknesses in the financial and economic system long before a systemic banking crisis emerges. This suggests that early warning indicators for systemic banking crises might have important role in monitoring and analysing economic developments, and therefore in conducting monetary policy. This paper represents an initial step in creating an early warning model for systemic banking crises for countries from the sample. While there are no perfect models, it would be very useful to have a tool that might help in maintaining banking system stability. The efforts in developing the adequate early warning model for systemic banking crises should contribute to financial system stability. A stable and reliable financial system represents one of the main prerequisites for a stable economic system and, accordingly, for economic growth and development. This paper represents an attempt to create an adequate basis for future research on the topic since further elaboration is necessary. 


\section{REFERENCES}

1. Ahec-Šonje, A. (1999). "Leading Indicators of Currency and Banking Crises: Croatia and the World". Croatian Economic Survey, 1996-1999: 273-313.

2. Ahec-Šonje, A. (2002). "Sensitivity Analysis of the Banking System - Signal Approach". Economic Review, 53 (9-10) 807-848.

3. Asanović, Ž. (2017). "Predicting Systemic Banking Crises Using Early Warning Models: The Case of Montenegro". Podgorica: Journal of Central Banking Theory and Practice, Vol. 6, No. 3, pp. 157-182.

4. Bokan, N. et al. (2009). "The Impact of the Financial Crisis and Policy Responses in Croatia". Zagreb: Croatian National Bank.

5. Bučevska, V. (2011). "An Analysis of Financial Crisis by an Early Warning System Model: The Case of the EU Candidate Countries", Prague: Prague Development Center, Business and Economic Horizons, Vol. 4, Issue 1, pp. 13-26.

6. Claessens, S. \& Van Horen, N. (2012). "Foreign Banks: Trends, Impact and Financial Stability". Washington, DC: International Monetary Fund, Working Paper No. 12/10.

7. Cull, R. \& Martínez Pería, M. S. (2007). "Foreign Bank Participation and Crises in Developing Countries". Washington, DC: World Bank, Policy Research Working Paper 4128.

8. Dardac, N. \& Boitan, I. A. (2009). "A Simple Early Warning System for Evaluating the Credit Portfolio's Quality". Theoretical and Applied Economics, pp. 69-78.

9. Davis E. P. \& Dilruba, K. (2008). "Could Early Warning Systems Have Helped to Predict the Subprime Crises?". Brunel University and NIESR West London, Economics and Finance Working Paper.

10. Demirgüç-Kunt, A., Ross, L. \& Min, H. G. (1998). "Opening to Foreign banks: Issues of Stability, Efficiency, and Growth". World Bank mimeo.

11. Demirgüç-Kunt, A. \& Detragiache, E. (1998). ”Financial Liberalization and Financial Fragility". Washington, DC: International Monetary Fund, Working Paper No. 83.

12. Dumičić, M. (2016). "Financial Stability Indicators - The Case of Croatia". Podgorica: Journal of Central Banking Theory and Practice, Vol 5, No 1, pp. 113-140.

13. Eichengreen, B. \& Rose, A. (1998). "Staying Afloat When the Wind Shifts: External Factors and Emerging-Market Banking Crises". NBER Working Paper No 6370.

14. Estrin, S. \& Uvalić, M. (2013). "Foreign Direct Investment into Transition Economies: Are the Balkans Different? ", LSE "Europe in Question" Discussion Paper Series No 64/2013 
15. Fabris, N. \& Galić, J. (2015). "Essay on Saving and Consumption". Podgorica: Journal of Central Banking Theory and Practice, Vol 4, No 3, pp. 123-136.

16. Frankel, J. A. \& Saravelos, G. (2010). ”Are Leading Indicators of Financial Crises Useful for Assessing Country Vulnerability? Evidence From the 2008-09 Global Crisis”. National Bureau of Economic Research, Working Paper No 16047.

17. Gujarati, D. N. (2004). Basic Econometrics. Fourth edition. New York: McGraw-Hill.

18. Hardy, D. C. \& Tieman, A. F. (2008). "Innovation in banking and excessive loan growth". Washington, DC: International Monetary Fund.

19. IMF. (2013). "Central, Eastern and Southeastern Europe". Washington, DC: International Monetary Fund. Regional Economic Issues.

20. Jagtiani, J., et al. (2003). "Early Warning Models for Bank Supervision: Simpler Could Be Better", Federal Reserve Bank of Chicago, 3Q/2003. Economic Perspectives: 49-60.

21. Kaminsky, G. L. \& Reinhart, C. M. (1996). "The Twin Crises: The Causes of Banking and Balance-of-Payments Problems". Washington, DC: Board of Governors of the Federal Reserve System. International Finance Dicussion Papers No 544, pp 473-500.

22. Kaminsky, G. L., Lizondo, S. \& Reinhart, C. M. (1998). ”Leading Indicators of Currency Crises". Washington, DC: International Monetary Fund, IMF Stuff Papers Vol 45, No 1.

23. Kindleberger, C. P. \& Aliber, R. Z. (2005). Manias, Panics and Crashes: A History of Financial Crises. Fifth edition, Palgrave Macmillan.

24. Laeven, L. \& Valencia, F. (2012). "Systemic Banking Crises: An Update". Washington, DC: International Monetary Fund, Working Paper No. 163.

25. Reinhart, C. M., Goldstein, M. \& Kaminsky, G. L. (2000). ”Assessing Financial Vulnerability, an Early Warning System for Emerging Markets: Introduction". Munich Personal RePEc Archive.

26. Schularick, M. \& Taylor, A. M. (2009). "Credit Booms Gone Bust. Monetary Policy, Leverage Cycles and Financial Crises, 1870-2008”. National Bureau of Economic Research, Working Paper No 15512.

27. Tang, H., Zoli, E. \& Klytchnikova, I. (2000). "Banking Crises in Transition Economies Dealt with Banking Crises: Fiscal Costs and Related Issues". World Bank, Europe and Central Asia Region, Poverty Reduction and Economic Management Sector Unit, Policy Research Working Paper No 2484, Washington, D.C.

28. Zhuang, J. Asian Development Bank (Ed). (2005). Early Warning Systems for Financial Crises: Applications to East Asia. New York: Palgrave Macmillan. 